\title{
MENGUKUR KEBERHASILAN PENERAPAN SISTEM INFORMASI AKADEMIK DENGAN MODEL KESUKSESAN DELON AND MCLEAN
}

\author{
Nur Nawaningtyas Pusparini ${ }^{\bowtie}$, Asrul Sani \\ Program Studi Teknik Informatika, STMIK Widuri, Jakarta, Indonesia \\ Email: tyaspusparini@kampuswiduri.ac.id
}

DOI: https://doi.org/10.46880/jmika.Vol4No2.pp149-155

\begin{abstract}
Academic information systems are designed to manage academic-related data using computer technology. The quality of the information system helps provide satisfaction for the organization and increases competitiveness, providing added value to STMIK Widuri. To measure the success of a system can apply the success model of Delone and McLean.By testing the system using DeLone and McLean it is known that the STMIK Widuri academic information system as a whole has a good quality system and scores $81.63 \%$.
\end{abstract}

Keywords: Academic, Delone and Mclean, Evalution.

\begin{abstract}
ABSTRAK
Sistem informasi akademik dirancang untuk mengelola data terkait akademik menggunakan teknologi komputer. Kualitas sistem informasi membantu memberikan kepuasan bagi organisasi dan meningkatkan daya saing, memberikan nilai tambah bagi STMIK Widuri. Untuk mengukur keberhasilan suatu sistem dapat menerapkan model keberhasilan Delone dan McLean. Dengan menguji sistem menggunakan DeLone dan McLean diketahui bahwa sistem informasi akademik STMIK Widuri secara keseluruhan memiliki sistem kualitas yang baik dan skor $81,63 \%$.
\end{abstract}

Kata Kunci: Akademik, Delone and Mclean, Evaluasi.

\section{PENDAHULUAN}

Sistem informasi akademik dirancang untuk mengelola data yang berkaitan dengan akademik yang menerapkan teknologi komputer baik itu hardware maupun software. Proses dikelola menjadi sebuah informasi yang memberikan dampak positif serta manfaat untuk pengelolaan manajemen perguruan tinggi. Tujuan dari sistem informasi akademik adalah mendukung penyelenggaraan pendidikan, dan juga menyediakan layanan informasi kepada mahasiswa. Karena kebutuhan dalam bidang pendidikan dan peraturan yang semakin lama semakin kompleks, membuat pengelolaan akademik pada suatu perguruan tinggi menguras waktu, tenaga dan pikiran.

Pada Perguruan Tinggi sering terjadi permasalahan terkait keterbatasan pengolahan data bermulai dari saringan ujian masuk, kemudian dilanjutkan dengan memberikan pengumuman hasil calon mahasiswa yang lulus, setelah proses pendaftaran ulang untuk mahasiswa, mengisi kartu rencana studi, mencetak kartu hasil studi, pendaftaran cuti, pencetakan transkip dan masih banyak lagi.

Kesulitan yang sering terjadi adalah banyak proses di dalam mengolah data dilakukan dalam waktu yang cepat. Mahasiswa menginginkan semua transaksi yang dilakukan dapat terselesaikan dengan mudah dan cepat serta informasi yang diinginkan sesuai dengan kebutuhan mereka. Dari kesulitan yang terjadi, maka menerapkan sistem teknologi informasi dalam sebuah proses kegiatan organisasi diharapkan akan berjalan sukses dalam pelaksanaanya, selain itu kesuksean sistem teknologi informasi sangat diperlukan suatu pengukuran supaya manajemen dapat mengetahui nilai tambah untuk suatu organisasi itu sendiri (Yuliana, 2016).

Kita bisa lihat sendiri saat ini sudah banyak organisasi yang memanfaatkan sistem informasi dalam hal pelayanan dimana kesuksesan dari sebuah teknologi informasi yang digunakan suatu organsasi. Berkenaan dengan suksesnya teknologi informasi yang digunakan berhubungan dengan adanya kepentingan (stakeholder). Dijelaskan juga bahwa ada tujuh kelompok pemegang kepentingan atau stakeholder terhadap pengembangan teknologi informasi suatu organisasi diantaranya adalah pengguna, industri (Jogiyanto, 2005).

Keberadaan pemegang kepentingan inilah yang dapat mengetahui apakah suatu sistem informasi berjalan sukses atau tidak. Selain itu juga Teknologi Informasi dapat memberikan suatu manfaat seperti 
nilaipositif bagi organisasi itu sendiri jika dirancang sistem informasi menjadi efektif dan efesien dan mempermudah user dalam pekerjaannya.

Saat ini STMIK Widuri sudah memiliki sistem informasi akademik (SIAKAD) yang sudah berjalan hampir 4 tahun. Sistem informasi akademik ini memberikan nilai tambah bagi STMIK Widuri, namun pengukuran atau penilaian kualitas sistem informasi ini belum dilakukan. Oleh sebab itu tujuan dari penelitian adalah melakukan penilaian kualitas sistem informasi ini apakah menghasilkan dampak kepuasan dan memberikan dampak positif bagi organisasi.

Untuk mengenali faktor-faktor yang dapat memberikan kesuksesan sistem teknologi informasi maka peneliti menggunakan DeLone and McLean untuk mengukur keberhasilan sistem teknologi informasi yang terdapat 6 komponen yang dapat mengukur kesuksesan sistem informasi diantaranya kualitas sistem (System Quality), kualitas informasi (Information Quality), kepuasan pengguna (User Satisfaction), penggunaan (Use), dampak individual (Individual Impact) dan dampak organisasi (Organizational Impact) (Yuliana, 2016).

Dari penjelasan diatas diharapkan dengan sistem informasi akademik dapat mengisi kebutuhan akademik sehingga kinerja sumber daya manusia, kualitas pelayanan, daya saing antar perguruan tinggi lain dapat meningkat. Untuk melakukan pengukuran kesuksesan suatu sistem informasi dapat menggunakan model kesuksesan Delone and McLean. Penelitian ini akan membahas faktor - faktor yang dapat mempengaruhi kesuksesan sistem infromasi jika dilihat dari sudut pandang model kesuksesan Delone and McLean.

\section{KAJIAN LITERATUR \\ Perkembangan Model Kesuksesan DeLone and McLean}

Di tahun 1992 William H. DeLone and Ephraim R. McLean membuat model yang dapat mempengaruhi hasil dari sistem informasi, enam dimensi tersebut meliputi System Quality, Information Quality, Use, User Satisfaction, Individual Impact dan Organizational Impact. Dengan model ini akan menerangkan bagaimana kualitas sistem dapat mempengaruhi penggunaan sistem dan kepuasan pengguna, selain itu kualitas dari sebuah informasi juga berpengaruh pada penggunaan dan kepuasan pengguna. Dimana hal ini berpengaruhi pada individual impact dan dampaknya akan mempengaruhi organizational impact.

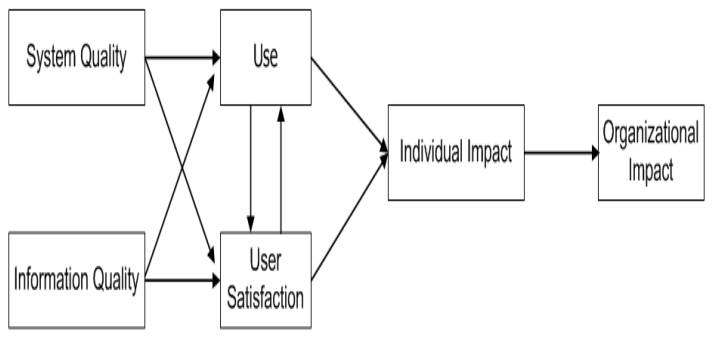

Gambar 1. Model Kesuksesan Sistem Informasi DeLone and McLean (1992)

Sumber: (Wu \& Wang, 2006)

Berikut penjelasan Model DeLone and McLean yaitu System Quality digunakan sebagai alat pengukur dari kualitas sistem teknologi informasi itu sendiri. Contohnya ketika dalam mengunduh, waktu unduh sangat penting oleh pengguna sistem. Sedangkan Information Quality digunakan sebagai alat pengukur kualitas keluaran dari sistem informasi, dimana kualitas informasi harus lengkap, relevan, mudah dipahami dan aman ketika digunakan oleh pengguna. Pada Use dapat mengukur penggunaan keluaran sistem oleh pemakai atau penerima, secara sederhananya adalah Use juga mengukur aktifitas kunjungan pengguna ketika menggunakan sistem di dalam bertransaksi dan pengambilan keputusan. User Satisfaction merupakan respon dari pemakai terhadap penggunaan keluaran sistem informasi tersebut. Pada user satisfaction dianggap sebagai cara penting dikarenakan dapat mengukur sebuah opini dari pengalaman pengguna mengenai sistem yang digunakan. Pada Individual Impact memberikan efek dari informasi yang digunakan terhadap perilaku pengguna. Organizational Impact akan memberikan pengaruh informasi yang digunakan terhadap kinerja organisasi.

Hubungan antara kualitas sistem serta kualitas informasi mempengaruhi baik dari segi penggunaan (Use) dan kepuasan pengguna (User Satisfaction). Penggunaan (Use) dapat memberikan pengaruh terhadap nilai dari kepuasan pengguna secara positif dan negatif. Penggunaan (Use) dan kepuasan pemakai (User Satisfaction) berpengaruh pada individual (Individual Impact) begitu juga dengan dampak organisasi (Organizational Impact). Dan pada tahun 2003, DeLone and McLean mengusulkan sebuah model yang telah dimodifikasi untuk mengatasi dari perubahan kebutuhan manajemen dan pengguna di era e-commerce. 


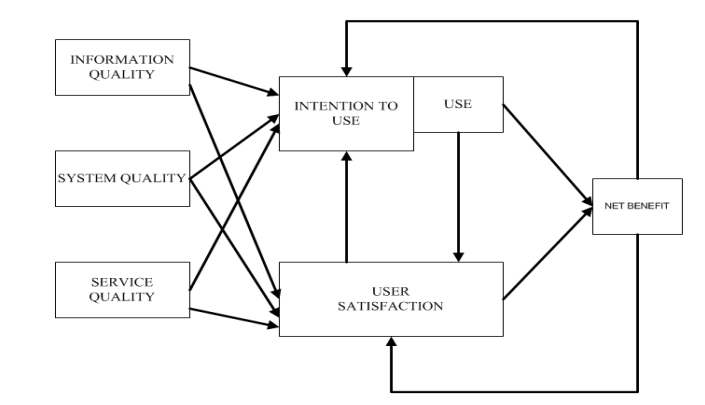

Gambar 2. Model Kesuksesan Baru DeLone and McLean

Sumber: (DeLone \& McLean, 2004)

Di dalam model kesuksesan DeLone and McLean ada enam elemen atau faktor untuk pengukuran diantaranya: (1) kualitas sistem (System Quality), (2) kualitas informasi (Information Quality), (3) kualitas pelayanan (Service Quality), (4) penggunaan (Use), (5) kepuasan pengguna (User Satisfaction), dan (6) manfaat bersih (Net Benefit). Berikut penjelasan mengenai 6 elemen atau faktor dari pengukuran model kesuksesan Delone and McLean (Wisudiawan, 2015) :

a. Kualitas Informasi (Sytem Quality) adalahframework sistem yang menunjukkan kemampuan perangkatnya. Kualitas sistem bertujuan untuk mengukur dari kemudahan penggunaan. Kualitas sistem diukur menggunakan parameter diantaranya adalah kegunaan (Usability), ketersediaan (Availability), keandalan (Reliability), kemampuan beradaptasi (Adaptability) dan respon (Response).

b. Kualitas Informasi (Information Quality) digunakan untuk mengukur kualitas keluaran dari sebuah sistem. Kualitas informasi mengukur keakuratan (Accurancy), ketepatan waktu (Timeless), kelengkapan (Completeness), relevan (Relevance) dan format (Format).

c. Kualitas Layanan (Service Quality) adalah membandingkanharapan pengguna dan persepsi dari layanan nyata yang mereka terima. Komponen dari berhasilnya sistem merupakan bagian dari kualitas layanan. Berikut komponen untuk mengukur kualitas layanan yaitu nyata (Tangible), keandalan (Reability), kecepatan respon (Quick Responsiveness),jaminan (Assurance) dan empati (Empathy).

d. Pengguna (Use) atau Usage Intentionsditujukan untuk mengetahui seberapa sering pengguna informasi memakai sistem tersebut. Penggunaan sistem mengukur frekuensi penggunaan, waktu penggunaan, jumlah akses, pola penggunaan dan ketergantungan.

e. Kepuasan Pengguna (User Satisfaction) ialah responyang diberikan oleh pengguna terhadap penggunaan keluaran sistem. Pengukuran dari kepuasan pengguna di lihat dari indikator seperti keefektifan (Effectiveness), efesiensi (Efficiency), dan kepuasan (Satisfaction) terhadap sistem yang digunakan. Contoh User Interface (UI) dan User Experience (UX).

f. Manfaat Tambahan (Net Benefits) adalah ukuran dari keberhasilan yang paling penting dikarenakan manfaat tambahanmenerima keseimbangan antara dampak positif dan negative. Pada net benefit, sistem membahas terkait dampak, hasil serta manfaat dari sistem terhadap kebutuhan pengguna dan kesuksesan perusahaan. Contohnya adalah didalam pengambilan keputusan dan produktivitas agar menjadi lebih baik.

Dari penjelasan diatas dapat diambil kesimpulan bahwa Model Delone and McLean merupakan model untuk mengukur kesuksesan dari sistem informasi. Model ini mencerminkan ketergantungan dari enam pengukuran kesuksesan sistem informasi.

\section{Teknik Slovin}

Responden populasi untuk penelitian ini adalah mahasiswa dan mahasiswi STMIK Widuri yang berjumlah 367 orang. Tujuan dari penggunaan teknik Slovin ini adalah mempersempit populasi dengan menghitung ukuran sampel. Jumlah sampel yang digunakan didasarkan pada rumus berikut:

$$
\mathrm{n}=\frac{\mathrm{N}}{1+\mathrm{N}(e)^{2}}
$$

Sumber: (Prastyo et al., 2015)

Keterangan:

$$
\begin{aligned}
& \mathrm{n}=\text { ukuran sampel/jumlah responden } \\
& \mathrm{N}=\text { ukuran populasi } \\
& \mathrm{e}=\text { batas toleransi kesalahan (error tolerance) }
\end{aligned}
$$

\section{Teknik Purposive Sampling}

Proses pemilihan elemen dari populasi dengan mempelajari sampel, memahami karakteristika subjek sampel merupakan bagian dari penyampelan (Pusparini et al., 2020). Di dalam purposive sampling, sampel dapat ditentukan sendiri, sampel juga diambil karena ada pertimbangan tersendiri, dimana sampel tidak diambil secara acak. Purposive sampling relatif mudah dan murah dalam pelaksanaan ukuran sampel 
juga dapat kurang dari 20 sampel, selain itu sampel dipilih berdasarkan individu yang dapat didekati.

\section{Sistem Informasi Akademik}

Seperti kita ketahui bahwa konon istilah Akademik berasal dari kata academus yang berarti sebuah taman umum yang berada di sebelah barat laut kota Athena. Nama Academus sendiri adalah nama seorang pahlawan pada masa perang Troya. Filosof Socrates menggunakan taman umum untuk berpidato dan membuka arena perdebatan tentang berbagai hal (Benedi, 2014). Dari kata academus berubah menjadi akademik, yang memiliki pengertian tempat perguruan dan para pengikut dari perguruan tersebut academist, sedangkan untuk perguruan semacam itu disebut academia. Berdasarkan hal itu, maka akademik adalah keadaan orang - orang yang dapat menyampaikan, menerima gagasan, pemikiran, ilmu pengetahuan serta sekaligus dapat mengujinyasecara jujur, terbuka dan leluasa (Benedi, 2014).

Sistem informasi akademik dirancang untuk keperluanpengelolaan data - data yang berkaitan dengan akademik dimana penerapan teknologi komputer digunakan baik itu perangkat keras dan perangkat lunak yang bertujuan untuk memberikan informasi kepada mahasiswa, dosen tentang data mahasiswa, kehadiran mahasiswa, data prestasi mahasiswa, data nilai mahasiswa, pembayaran perkuliahan, jadwal perkuliahan dan masih banyak lain (Yunita et al., 2013).

Selain itu sistem informasi akademik adalah sebuah sistem informasi manajemen di bidang pendidikan, sistem informasi akademik merupakan sekumpulan interaksi sistem - sistem informasi yang menyediakan informasi kebutuhan akademik (Yunita et al., 2013).

Sistem informasi akademik merupakan sistem yang menangani masalah - masalah akademik untuk memantau prestasi yang telah dicapai dalam proses belajar mengajar. Di dalam sistem seorang mahasiswa dapat mengetahui nilai mahasiswa, keuangan dan presensi mahasiswa. Prosedur kerja untuk kegiatan akademik yaitu dimulai dari proses pendaftaran calon mahasiswa baru yang akan mengikuti proses belajar mengajar (Saputra et al., 2013).

Dari penjelasan semua diatas dapat disimpulkan bahwa sistem informasi akademik merupakan sistem yang dibuat untuk mempermudah semua kegiatan administrasi akademik yang dilakukan di kampus dimana sistem tersebut di atur secara online.

\section{METODE PENELITIAN Alur Penelitian}

Untuk penelitian ini, menggunakan metode penelitian kualitatif deskriptif dan alur penelitian seperti pada Gambar 4 terdapat beberapa tahapan dalam penelitian. Adapun tahapan - tahapan seperti identifikasi permasalah, pada tahapan ini penulis melakukan proses inisialisasi penelitian dengan mengidentifikasi dan merumuskan sebuah permasalahan yang terjadi. Pengumpulan Data, untuk tahapan pengumpulan data dilakukan dengan cara observasi dengan pengamatan langsung di objek penelitian dan wawancara terhadap bagian terkait. Untuk Studi Pustaka \& Tinjauan Penelitian, pada tahapan ini dilakukan studi literature dan analisis dari penelitian sebelumnya. Dimana penulis mempelajari studi pustaka yang berhubungan dengan model kesuksesan DeLone and McLean dan teori yang terkait.

Menentukan Model Penelitian, pada tahapan ini penulis menggunakan metode deskriptif kuantitatif dan kualitatif di dalam analisa data. Tahap Analisis, untuk tahap analisis, penulis menyiapkan sebuah questioner untuk dibagikan kepada responden. Pengujian, pada tahapan pengujian untuk mengevaluasi sistem informasi akademik dengan menggunakan Model Kesuksesan DeLone and McLean. Pembuatan Laporan, untuk tahapan ini penulis melakukan pembuatan laporan akhir berupa kesimpulan dan hasil dari penelitian yang sudah dilakukan.

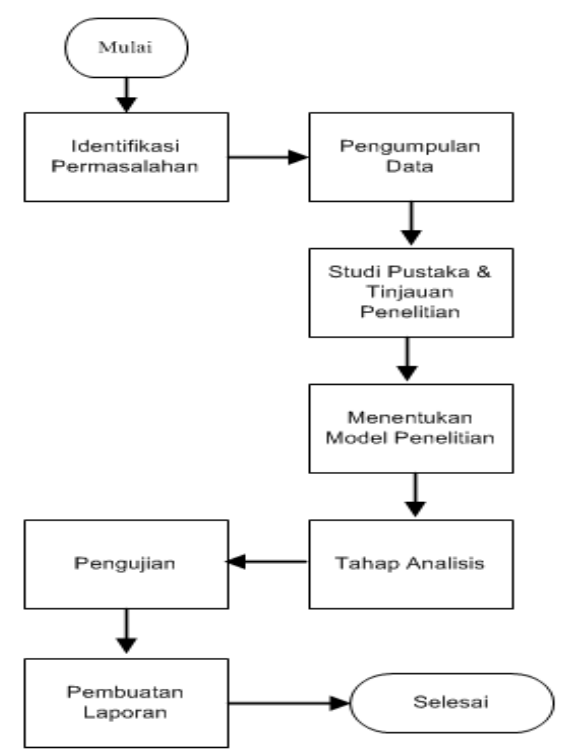

Gambar 4. Metodologi Penelitian 


\section{Metode Pemilihan Sampel}

Pada penelitian ini, terdapat 79 responden yang terdiri dari mahasiswa/i untuk menguji sistem dengan menggunakanteknik Slovin untuk menentukan jumlah responden dan untuk wawancara penulis menggunakan purposive sampling pada tahapan wawancara kepada unit administrasi akademik.

\section{HASIL DAN PEMBAHASAN}

\section{Analisis Hasil Pengujian}

Analisis Hasil Pengujian Sistem Informasi Akademik dengan Model Kesusksesan DeLone and McLean. Pengujian kualitas model dengan mengadopsi DeLone and McLean model yaitu Information Quality, System Quality, Service Quality, Use, User Satisfaction dan Net Benefit. (Surono, 2020)

Dalam memberikan jawaban dari kuesioner yang diberikan dibuat skala pengukuran sebagai berikut:

Tabel 1. Skala Pengukuran

\begin{tabular}{|l|l|l|}
\hline Indikator & \multicolumn{1}{|c|}{ Keterangan } & $\begin{array}{c}\text { Bobot } \\
\text { Nilai }\end{array}$ \\
\hline SS & Sangat Setuju & 5 \\
\hline S & Setuju & 4 \\
\hline CS & Cukup Setuju & 3 \\
\hline TS & Tidak Setuju & 2 \\
\hline STS & Sangat Tidak Setuju & 1 \\
\hline
\end{tabular}

Sumber: (Surono, 2020)

Tabel 2. Presentase Untuk Tanggapan Responden Terhadap Skor Ideal

\begin{tabular}{|l|l|}
\hline \% Jumlah Skor & Kriteria \\
\hline $20,00 \%-36,00 \%$ & Sangat Buruk \\
\hline $36,01 \%-52,00 \%$ & Buruk \\
\hline $52,01 \%-68,00 \%$ & Cukup \\
\hline $68,01 \%-84,00 \%$ & Baik \\
\hline $84,01 \%-100 \%$ & Sangat Baik \\
\hline \multicolumn{2}{|c|}{ Sumber: (Pusparini et al., 2020) }
\end{tabular}

Untuk table presentase pengujian sistem dengan Model Kesuksesan DeLone and McLean sebagai berikut.

1. Presentase skor model aspek kualitas informasi (Information Quality).

Tabel 3. Aspek Information Quality

\begin{tabular}{|l|l|r|r|r|r|l|}
\hline Jawaban & Bobot & $\mathbf{1}$ & $\mathbf{2}$ & $\mathbf{3}$ & $\mathbf{4}$ & Total \\
\hline SS & 5 & 10 & 15 & 15 & 18 & 58 \\
\hline S & 4 & 13 & 16 & 10 & 15 & 54 \\
\hline CS & 3 & 20 & 20 & 20 & 15 & 75 \\
\hline TS & 2 & 25 & 13 & 14 & 16 & 68 \\
\hline STS & 1 & 11 & 15 & 20 & 15 & 61 \\
\hline Jumlah Responden & 79 & 79 & 79 & 79 & 316 \\
\hline \multicolumn{2}{|l|}{ Skor Aktual } & 223 & 240 & 223 & 242 & 928 \\
\hline \multicolumn{2}{|l}{ Skor Ideal } & 316 & 316 & 316 & 316 & 1264 \\
\hline
\end{tabular}

Tabel diatas merupakan hasil penilaian kuesioner untuk aspek Information Quality. Dengan hasil skor aktual sebagai berikut:

$$
\begin{aligned}
& \% \text { Skor Aktual }=\frac{\text { SkoraktualInformationQuality }}{\text { SkorIdealInformationQuality }} \\
& \% \text { Skor Aktual }=\frac{928}{1264} \times 100 \%=73,41 \% \frac{1250}{1264}
\end{aligned}
$$

2. Persentase skor model untuk aspek kualitas sistem (System Quality)

Tabel 4. Aspek System Quality

\begin{tabular}{|l|l|r|r|r|r|l|}
\hline Jawaban & Bobot & $\mathbf{5}$ & $\mathbf{6}$ & $\mathbf{7}$ & $\mathbf{8}$ & Total \\
\hline SS & 5 & 20 & 10 & 21 & 17 & 68 \\
\hline S & 4 & 20 & 15 & 18 & 16 & 69 \\
\hline CS & 3 & 19 & 20 & 20 & 15 & 74 \\
\hline TS & 2 & 15 & 19 & 12 & 18 & 64 \\
\hline STS & 1 & 5 & 15 & 8 & 13 & 42 \\
\hline Jumlah Responden & 79 & 79 & 79 & 79 & 316 \\
\hline Skor Aktual & 272 & 223 & 269 & 243 & 1007 \\
\hline \multicolumn{2}{|l|}{ Skor Ideal } & 317 & 317 & 317 & 317 & 1268 \\
\hline
\end{tabular}

Tabel diatas merupakan hasil penilaian kuesioner untuk aspek System Quality. Dengan hasil skor aktual sebagai berikut :

$$
\% \text { Skor Aktual }=\frac{1185}{1268} \frac{1007}{1268} \times 100 \%=79,41 \%
$$

3. Persentase skor model untuk aspek kualitas Layanan (Service Quality)

Tabel 5. Aspek Service Quality

\begin{tabular}{|l|l|c|c|c|l|}
\hline Jawaban & Bobot & $\mathbf{9}$ & $\mathbf{1 0}$ & $\mathbf{1 1}$ & Total \\
\hline SS & 5 & 10 & 13 & 12 & 35 \\
\hline S & 4 & 11 & 13 & 12 & 36 \\
\hline CS & 3 & 15 & 19 & 10 & 44 \\
\hline TS & 2 & 30 & 20 & 22 & 72 \\
\hline STS & 1 & 13 & 14 & 23 & 50 \\
\hline Jumlah Responden & 79 & 79 & 79 & 237 \\
\hline Skor Aktual & 212 & 228 & 205 & 645 \\
\hline \multicolumn{2}{|l|}{ Skor Ideal } & 237 & 237 & 237 & 711 \\
\hline
\end{tabular}

Tabel diatas merupakan hasil penilaian kuesioner untuk aspek Service Quality. Dengan hasil skor aktual sebagai berikut :

$$
\% \text { Skor Aktual }=\frac{1185}{1268} \frac{645}{711} \times 100 \%=90,71 \%
$$


4. Persentase skor model untuk aspek Pengguna (Use)

Tabel 6. Aspek Use

\begin{tabular}{|l|l|l|l|l|l|l|}
\hline Jawaban & Bobot & $\mathbf{1}$ & $\mathbf{2}$ & $\mathbf{3}$ & $\mathbf{4}$ & Total \\
\hline SS & 5 & 29 & 15 & 17 & 20 & 81 \\
\hline S & 4 & 20 & 25 & 20 & 25 & 90 \\
\hline CS & 3 & 12 & 24 & 20 & 19 & 75 \\
\hline TS & 2 & 13 & 10 & 15 & 11 & 49 \\
\hline STS & 1 & 5 & 5 & 7 & 4 & 21 \\
\hline Jumlah Responden & 79 & 79 & 79 & 79 & 316 \\
\hline Skor Aktual & 292 & 272 & 262 & 283 & 1109 \\
\hline \multicolumn{2}{|l|}{ Skor Ideal } & 316 & 316 & 316 & 316 & 1264 \\
\hline
\end{tabular}

Tabel diatas merupakan hasil penilaian kuesioner untuk aspek Use. Dengan hasil skor aktual sebagai berikut :

$$
\% \text { Skor Aktual }=\frac{1185}{1268} \frac{1109}{1264} \times 100 \%=87,73 \%
$$

5. Persentase skor model untuk aspek Kepuasan Pengguna (User Satisfaction)

Tabel 7 . Aspek User Satisfaction

\begin{tabular}{|l|l|l|l|l|l|l|}
\hline Jawaban & Bobot & $\mathbf{1}$ & $\mathbf{2}$ & $\mathbf{3}$ & $\mathbf{4}$ & Total \\
\hline SS & 5 & 17 & 14 & 14 & 17 & 62 \\
\hline S & 4 & 20 & 17 & 18 & 14 & 69 \\
\hline CS & 3 & 20 & 21 & 20 & 20 & 81 \\
\hline TS & 2 & 16 & 15 & 18 & 13 & 62 \\
\hline STS & 1 & 6 & 12 & 9 & 15 & 42 \\
\hline Jumlah Responden & 79 & 79 & 79 & 79 & 316 \\
\hline \multicolumn{2}{|l|}{ Skor Aktual } & 263 & 243 & 243 & 242 & 991 \\
\hline \multicolumn{2}{|l}{ Skor Ideal } & 316 & 316 & 316 & 316 & 1264 \\
\hline
\end{tabular}

Tabel diatas merupakan hasil penilaian kuesioner untuk aspek Use. Dengan hasil skor aktual sebagai berikut :

$\%$ Skor Aktual $=\frac{1185}{1268} \frac{991}{1264} \times 100 \%=78,40 \%$

6. Persentase skor model untuk aspek Manfaat Tambahan (Net Benefit)

Tabel 8. Aspek Net Benefit

\begin{tabular}{|l|l|l|l|l|l|l|}
\hline Jawaban & Bobot & $\mathbf{2 0}$ & $\mathbf{2 1}$ & $\mathbf{2 2}$ & $\mathbf{2 3}$ & Total \\
\hline SS & 5 & 17 & 10 & 15 & 15 & 57 \\
\hline S & 4 & 20 & 19 & 25 & 20 & 84 \\
\hline CS & 3 & 25 & 21 & 12 & 19 & 77 \\
\hline TS & 2 & 11 & 17 & 20 & 15 & 63 \\
\hline STS & 1 & 6 & 12 & 7 & 10 & 35 \\
\hline Jumlah Responden & 79 & 79 & 79 & 79 & 316 \\
\hline \multicolumn{2}{|l|}{ Skor Aktual } & 268 & 235 & 258 & 252 & 1013 \\
\hline \multicolumn{2}{|l|}{ Skor Ideal } & 316 & 316 & 316 & 316 & 1264 \\
\hline
\end{tabular}

Tabel diatas merupakan hasil penilaian kuesioner untuk aspek Net Benefit. Dengan hasil skor aktual sebagai berikut :

$\%$ Skor Aktual $=\frac{1185}{1268} \frac{1013}{1264} \times 100 \%=80,14 \%$

Keterangan untuk pertanyaan dalam penyebaran kuesioner.

Tabel 9. Pertanyaan untuk DeLone and McLean

\begin{tabular}{|c|c|}
\hline No & Pertanyaan \\
\hline \multicolumn{2}{|c|}{ Kualitas Informasi (Information Quality) } \\
\hline 1. & 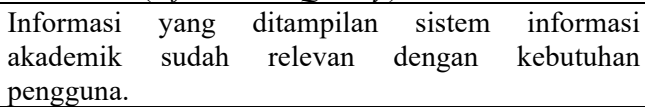 \\
\hline 2 & $\begin{array}{l}\text { Pengguna merasa informasi yang ditampilkan } \\
\text { sistem.mudah dipahami. }\end{array}$ \\
\hline 3 & Pengguna merasa informasi yang munculberkualitas. \\
\hline 4 & $\begin{array}{l}\text { Pengguna merasa informasi yang ditampilkan sesuai } \\
\text { dengan kondisi terkini. }\end{array}$ \\
\hline \multicolumn{2}{|c|}{ Kualitas Sistem (System Quality) } \\
\hline 5 & Sistem mudah digunakan. \\
\hline 6 & $\begin{array}{l}\text { Informasi yang muncul pada sistemsesuai dengan } \\
\text { kebutuhan pengguna }\end{array}$ \\
\hline 7 & Sistem nyaman digunakan. \\
\hline 8 & $\begin{array}{l}\text { Sistem terasa cepat dalam merespon instruksi } \\
\text { pengguna. }\end{array}$ \\
\hline \multicolumn{2}{|c|}{ Kualitas Pelayanan (Service Quality) } \\
\hline 9 & $\begin{array}{l}\text { Mayoritas fitur dan fungsi dalam sistem terasa } \\
\text { berguna bagi pengguna. }\end{array}$ \\
\hline 10 & $\begin{array}{l}\text { Pengguna merasa informasi yang ditampilkan sistem } \\
\text { informasi bisa dipercaya. }\end{array}$ \\
\hline 11 & $\begin{array}{l}n \text { informasi sistem informasi sesuai dengan } \\
\text { an pengguna. }\end{array}$ \\
\hline \multicolumn{2}{|c|}{ Pengguna (Use) } \\
\hline 12 & $\begin{array}{l}\text { Pengguna menggunakan sistem informasi akademik } \\
\text { secara langsung tidak meminta orang lain untuk } \\
\text { menggunakan. }\end{array}$ \\
\hline 13 & $\begin{array}{l}\text { Pengguna rutin di dalam menggunakan sistem } \\
\text { informasi akademik. }\end{array}$ \\
\hline 14 & $\begin{array}{l}\text { Pengguna didalam menggunakan sistem informasi } \\
\text { dalam waktu yang lama. }\end{array}$ \\
\hline 15 & $\begin{array}{l}\text { Sistem informasi akademik dapat digunakan secara } \\
\text { gratis. }\end{array}$ \\
\hline \multicolumn{2}{|c|}{ Kepuasan Pengguna (User Satisfaction) } \\
\hline 16 & $\begin{array}{l}\text { Pengguna merasa puas dengan fitur dan fungsi yang } \\
\text { ada di dalam sistem. }\end{array}$ \\
\hline 17 & $\begin{array}{l}\text { Pengguna merasa puas dengan informasi yang } \\
\text { tersedia karena sesuai dengan kebutuhan pengguna. }\end{array}$ \\
\hline 18 & $\begin{array}{l}\text { Pengguna merasa menggunakan sistem informasi } \\
\text { akademik menyenangkan. }\end{array}$ \\
\hline 19 & $\begin{array}{l}\text { Pengguna merasa pas dengan sistem informasi } \\
\text { akademik yang andal. }\end{array}$ \\
\hline \multicolumn{2}{|c|}{ Manfaat Tambahan (Net Benefit) } \\
\hline 20 & $\begin{array}{l}\text { Sistem memudahkan pengguna dalam mengambil } \\
\text { keputusan terkait akademik. }\end{array}$ \\
\hline 21 & $\begin{array}{l}\text { Pengguna merasa } \\
\text { pelayanan kampus. }\end{array}$ \\
\hline 22 & $\begin{array}{l}\text { Pengguna merasa sistem } \\
\text { mewujudkan tujuan kampus. }\end{array}$ \\
\hline 23 & $\begin{array}{l}\text { Pengguna merasa sistem meningkatkan efektivitas } \\
\text { pelayanan kampus. }\end{array}$ \\
\hline
\end{tabular}


Tabel 10. Kesimpulan pengujian Delone And Mclean

\begin{tabular}{|c|l|c|c|c|}
\hline No & \multicolumn{1}{|c|}{ Aspek } & $\begin{array}{c}\text { Skor } \\
\text { Aktual }\end{array}$ & $\begin{array}{c}\text { Skor } \\
\text { Ideal }\end{array}$ & $\begin{array}{c}\text { Total } \\
\text { Skor }\end{array}$ \\
\hline 1 & $\begin{array}{l}\text { Information } \\
\text { Quality }\end{array}$ & 928 & 1268 & $73,41 \%$ \\
\hline 2 & System Quality & 1007 & 1268 & $79,41 \%$ \\
\hline 3 & $\begin{array}{l}\text { Service } \\
\text { Quality }\end{array}$ & 645 & 711 & $90,71 \%$ \\
\hline 4 & Use & 1109 & 1264 & $87,73 \%$ \\
\hline 5 & $\begin{array}{l}\text { User } \\
\text { Satisfaction }\end{array}$ & 991 & 1264 & $78,40 \%$ \\
\hline 6 & Net Benefit & 1013 & 1264 & $80,14 \%$ \\
\hline Total & & 5693 & 7039 & $81,63 \%$ \\
\hline
\end{tabular}

Tabel diatas menyimpulkan hasil pengujian kualitas sistem dengan enam aspek pengujian sistem, di dapat hasil kualitas informasi (information quality) sebesar 73,41 \%, kualitas sistem (system quality) sebesar 79,41\%, kualitas pelayanan (service quality) sebesar 90,71\%, pengguna (use) 87,73\%, kepuasan pengguna (user satisfaction) $78,40 \%$, manfaat tambahan (net benefit) 80,14 \%. Maka secara keseluruhan didapatkan rata rata nilai pengujian menggunakan metode Delone and McLean model sebesar 81,63 \% dan secara keseluruhan kualitas sistem ini berjalan dengan baik.

\section{KESIMPULAN}

Merujuk dari analisis dan pengujian maka dapat disimpulkan bahwa sistem informasi akademik dapat memenuhi kebutuhan akademik sehingga kinerja sumber daya manusia, kualitas pelayanan, daya saing antar perguruan tinggi lain menjadi lebih baik. Dengan pengujian sistem menggunakan DeLone and McLean diketahui bahwa terdapat faktor penting seperti system quality, information system,service quality, use, user satisfaction, net benefit dimana faktor- faktor tersebut penting untuk pengembangan sistem, selain itu sistem informasi akademik yang berjalan sekarang secara keseluruhan terdapat kualitas sistem berjalan dengan baik dan mendapat nilai 81,63\%. Dengan model Delone and McLean diketahui dapat mengukur sebuah kesuksesan dari sistem informasi, dimana model ini menggambarkan ketergantungan dari enam pengukuran kesuksesan sistem informasi.

\section{DAFTAR PUSTAKA}

Benedi, J. (2014). Pengembangan Sistem Informasi Akademik di SMK 1 Pundong untuk Meningkatkan Mutu Layanan Sekolah. Skripsi. Yogyakarta: Universitas Negeri Yogyakarta.

DeLone, W. H., \& McLean, E. R. (2004). Measuring e-commerce success: Applying the DeLone and McLean Information Systems Success Model.
International Journal of Electronic Commerce, 9(1), 31-47.

Surono, G., Pusparini, N. N. (2020). Sistem

Pendukung Keputusan Penentuan Siswa Teladan Menggunakan Metode Simple Additive Weighting (SAW) Studi Kasus: SD Bhakti YKKP. Journal of Technology Information, 6(1), 49-56.

Jogiyanto. (2005). Analisis dan Desain Sistem Informasi : Pendekatan Tersetruktur Teori dan Praktik Aplikasi Bisnis (III). Yogyakarta: Andi Offset.

Prastyo, W. R., Heddy, S., \& Nugroho, A. (2015). Identifikasi Tumbuhan Paku Epifit pada Batang Tanaman Kelapa Sawit (Elaeis guineensis j .) Di lingkungan Universitas Brawijaya. Jurnal Produksi Tanaman, 3(1), 65-74.

Pusparini, N. N., Budiyantara, A., \& Lusa, S. (2020). Pengaruh Knowledge Management System untuk Jenjang Jabatan. METHOMIKA: Jurnal Manajemen Informatika \& Komputerisasi Akuntansi, 4(1), 80-88.

Saputra, F., Hannah, M. P., \& Novita, D. (2013). Sistem Informasi Akademik Berbasis Web pada Global English Language Center. Skripsi. Palembang: STMIK MDP.

Wisudiawan, G. A. A. (2015). Analisis Faktor Kesuksesan Sistem Informasi Menggunakan Model Delone and Mclean. Jurnal Ilmiah Teknologi Informasi Terapan, 2(1), 55-59.

Wu, J. H., \& Wang, Y. M. (2006). Measuring KMS Success: A Respecification of the DeLone and McLean's Model. Information and Management, 43(6), 728-739.

Yuliana, K. (2016). Pos Indonesia (Persero) Divisi Regional Vi Semarang. Infokom, II(II), 13-23.

Yunita, R., Widana, A. \& Irfani, M. H. (2013). Sistem Informasi Akademik pada SMA Yanitas Palembang. Skripsi. Palembang: STMIK MDP. 